\title{
Creative industries in the capital cities of the Baltic States: Are there innovations in urban policy?
}

\author{
Külliki TAFEL-VIIA a *, Erik TERK ${ }^{\text {a }}$, Silja LASSUR ${ }^{\text {a }}$, Andres VIIA ${ }^{\text {a }}$
}

\begin{abstract}
The transformation of urban policy, resulting from 'creative industries' policy developments, is explored in this article, with respect to the Baltic capitals. Policy initiatives in the creative industries in Central and Eastern European cities have predominantly developed through policy transfers from Western Europe, with its longterm market economy experience. How adaptable are such policies for post-socialist cities? Using the concept of social innovation, this article describes mechanisms that facilitate policy acceptance and examines whether and how the development of creative industries has resulted in urban policy renewal in the Baltic capitals.
\end{abstract}

Keywords: creative industries, urban policy, social innovation, Baltic capitals (Tallinn, Riga and Vilnius)

\section{Introduction}

The increased role of cities as economic competitors together with the diversification of their functions, forces them continually to adjust policies in line with socioeconomic changes, while also providing new development targets. In recent decades, the concept of creative industries (CI) has become recognized as an important field for the cultural and economic vitality of (city) regions, providing significant economic resources especially through creating value, employment and image. This shift - the recognition of CI - is not restricted to the transformation of the economy, but is also closely related to changes in lifestyles, including the use of leisure time as well as changes in the role of culture (Bramham and Spink, 2009), and an increase in postmodern values (Beck, 1986). In developed (Western) economies, the significance of CI in local-level policies has been observable since the 1980s (Hesmondhalgh and Pratt, 2005). The emergence of a new policy stream - a creative industries policy - has shaken the backbone of several other policies, including cultural, economic, innovation, education and regional policies (Throsby, 2008; Wyszomirski, 2008; Potts and Cunningham, 2008).

In developed (Western) countries, however, such policies developed more or less alongside general socio-economic changes. In contrast, in the majority of post-socialist Central and Eastern European (CEE) countries, the ideology of CI was predominantly introduced via an initiative of the British Council (Jürisson, 2007; Primorac, 2006; Suciu, 2009). Thus, the main mechanism for the emergence of CI policy-related initiatives was policy transfer from the UK, and therefore, the development of CI policies can be considered (mainly) as a top-down innovation or reform in these countries (Lassur et al., 2010). As the support policy for CI has been considered quite location- and culture-specific, linked to the particular urban environment and the peculiarities of local cultures, this raises the question of whether and how the socio-economic context in CEE countries enables the transfer of new kinds of policies and supports their adoption and development.

In this article, we explore the transformation of urban policy which has resulted from the introduction and diffusion of the concept of CI in three post-socialist cities: Tallinn, Riga and Vilnius (Fig. 1). Compared to countries with long market-economy traditions, the capitals of the three Baltic States are 'newcomers' in terms of CI development, and have rarely been in the focus of CI policy studies. The fact that they are capital cities located in the same geographical region, with roughly similar populations and sharing a similar socio-economic background, makes them a good collective subject for such a study, as their starting positions and capacity for developing new policies seem similar. Following the concept of social innovation, we examine whether and what kinds of mechanisms can be identified in CI policies that facilitate the adoption and (successful) implementation of CI policies in the three Baltic capitals. The discussion is premised on the findings of an international study: "Creative Metropoles" (CM, 2010), that mapped the public CI policies in eleven European cities (including Tallinn, Riga and Vilnius) in 2009.

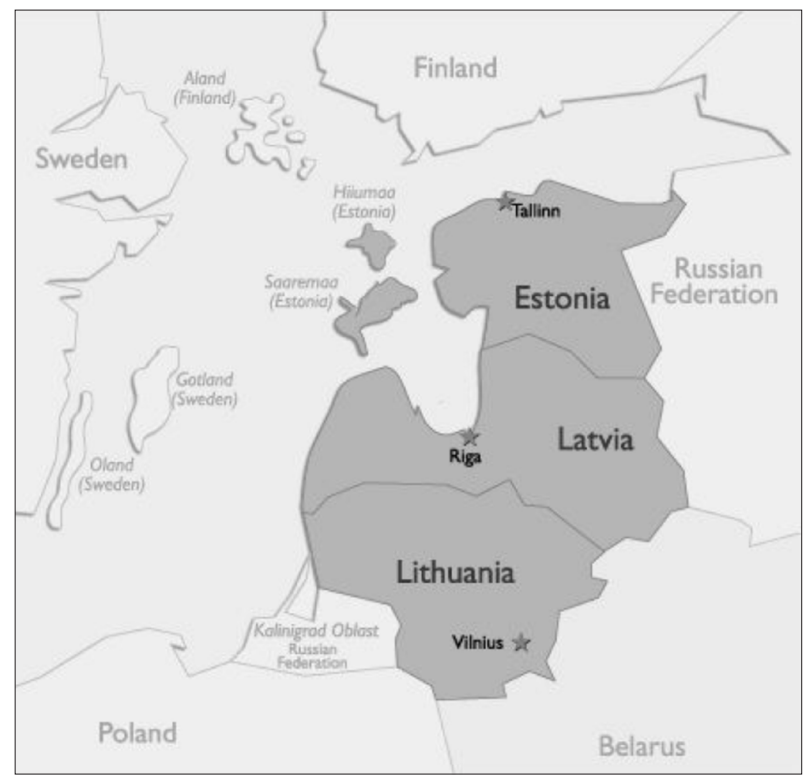

Fig. 1: Area under study

\footnotetext{
a Estonian Institute for Futures Studies, Tallinn University, Tallinn, Estonia (*corresponding author: K. TafelViia, e-mail: kylliki.tafel-viia@tlu.ee)
} 


\section{Explanation of $\mathrm{Cl}$ policies: social innovation approach}

In this article, CI policies are discussed in the context of the top-down transfer of the CI ideology and the development of the resulting policies. Regarding 'policy', we have followed Lodge (2007) and taken three key variables into focus: policy rationale; policy instruments or intervention mechanisms for supporting and developing CI; and governance of the policy process which includes certain conventional topdown patterns as well as horizontal or bottom-up processes, which take form in certain organisational or institutional arrangements (Lange et al., 2010). The focus is set on exploring how the implementation and acceptance of CI policy practices can be facilitated.

To explain the facilitation possibilities of CI policies we make use of the concept of social innovation (SI). We follow the wide-scope approach to SI (a narrow approach proceeds from the understanding that SI is induced by some kind of social need and/or is aimed at solving a critical social problem: see e.g. Mulgan, 2006; Nussbaumer and Moulaert, 2004) according to which SI is particularly concerned with processes and mechanisms that facilitate the process of adopting change. This kind of approach to SI stems from economic and technological, as well as organizational and management theories. These explain SI as an important 'enabling mechanism', facilitating the implementation and adoption of the 'main' innovation (Gopalakrishnan and Damnapour, 1997; Moulaert et al., 2005) - the ideology of CI and particularly CI policies in our context. In this case, the trigger for a SI is the need for structural adjustment due to reforms and/or radical (e.g. technological or economic) changes in the external environment. There are two main issues that illuminate "the power" of SI to facilitate the adoption and acceptance of change. On the one hand, SI is explained as change in multilevel social institutions (Heiskala, 2007) that encompasses regulative, normative and cultural elements of institutional change:

"Regulative innovations transform explicit regulations and/or the ways they are sanctioned. Normative innovations challenge established value commitments and/or the way the values are specified into legitimate social norms. Finally, cultural innovations challenge the established ways to interpret reality by transforming mental paradigms, cognitive frames and habits of interpretation. Taken together these three classes form the sphere of social innovations" (Heiskala, 2007: 59).

Accordingly, the concept of SI emphasizes that the innovation (CI policies in our context) to be implemented and adopted should be accompanied by changes in meanings, everyday practices and social structures (Tuomi, 2006). This suggests that changes should occur not only at the regulatory level (e.g. state reform) but also at the normative and cultural-cognitive levels of social institutions (Scott, 2001). On the other hand, the concept of SI also makes it possible to highlight certain social mechanisms that facilitate the process of innovation and bring about change at the level of subjective meaning.

Social innovation theorists (Marcey and Mumford, 2007; Heiskala and Hämäläinen, 2007; Tuomi, 2005) emphasize that the processes of interaction, learning and the attribution of subjective meanings to changes are closely related and fundamental to the innovation process, as shared understandings arise from these processes. These mechanisms can be seen as the 'carriers' of SI, thus helping to explain the implementation, adoption and adaptation of the innovation, making it part of social practice. From the perspective of SI, the "success" of an innovation can be assessed in terms of the depth of the change regarding institutional levels and the acceptance of the change by the actors the policy addresses. Applying the concept of SI in the context of CI policies can illuminate the importance of the interaction mechanisms that bring together CI policy makers and beneficiaries (e.g. CI sector representatives, policy makers from other fields, citizens, etc.) and support the diffusion of CI policy practices. Thus, the implementation of change through public policies requires certain mechanisms, initiatives and institutional settings - different forms of formal and informal social networks, options and spaces for knowledge exchange, involvement, arenas for collective learning - which all facilitate the sense-making, and therefore, support the adoption of the policies.

To analyze CI policies, we focus on identifying those mechanisms which: i) support the diffusion of new CIrelated knowledge and practices; and ii) are directly created to facilitate the acceptance of CI policies, including networks and other types of interaction instruments which bring together the policy-makers and the beneficiaries that the policies address.

Creative industries deal with discussing and (re)defining the relations between economy and culture; they bring together contact points or border zones of different activity systems (Engeström, 1987; Tuomi-Gröhn et al., 2003). Recent developments in the conceptualization of CI indicate that the understanding of CI has been moving from industry-based definitions towards market- and networkbased conceptualizations (Potts et al., 2008). By generalizing former discussions on CI and its policies, we can highlight the following three topics where the issue of interaction mechanisms has been revealed:

1. through the existence of interaction at the level of CI as a field;

2. through cooperation practices within the organizational structure of support for CI policy; and

3. through the beneficiaries of CI policies.

The existence of interaction within the field of CI and with other fields depends on the particular approach to CI. At the one end lies the sector-based approach (i.e. creative economy (Howkins, 2002) that determines CI as a group of certain sectors that constitute the spectrum of CI - or 'just another industry', if using Potts and Cunningham's (2008) approach. In terms of policy this means that CI is treated as an insulated sector policy (beside other policies). At the other end of the spectrum are approaches that explain CI in a wider sense/context. Here we may refer to concepts such as creative city (Landry, 2000) that can be described as all-embracing by capturing all kinds of fields related to urban development (Landry et al., 2005) or the concept of the experience economy (Pine II, Gilmore, 1999), which stresses the customer point of view - not only on developing CI, but on the economy in general. Florida's (2002) creative class concept also coincides with the wider approach to CI. He defines the creative class as consisting of people who add economic value through their creativity. His concept encompasses both 'traditional' creative fields, as well as a range of knowledge-intensive industries.

In principle, these approaches are based on the idea that activities supporting CI have cross-sector scope. The more recent approaches to CI (e.g. value-creating ecology, social 
network markets) define CI as network-based activities: the constellation of CI firms is dynamic and value flow is multi-directional and works through networks (Hearn et al., 2007). The findings from recent studies on CI policies indicate that there is an increasing tendency towards a comprehensive approach to creativity and a rise in creativity as strongly related to different fields. Major importance is attached to linking enhancements in CI to the policies and practices governing other sectors and fields (e.g. innovation and ICT). CI is increasingly included in innovation and other strategies supporting the tendencies towards the knowledge economy (Foord, 2008).

The second topic concerns the forms of interaction in terms of the organizational structure of the support for CI policy. As CI policy, due to its inter-disciplinarity, is a field of responsibility for several policy institutions, we may raise the question of whether the organizational structure of support is based on cooperation and enhances (new) forms of collaboration between different structures and institutions. A discussion has been growing in the theoretical discourse regarding whether the traditional structures of governance are suitable to CI due to its peculiar patterns of operation (Lange, 2009; Balducci, 2004; Kunzmann, 2004). CI challenges the structures and practices of governance in several ways, including: the blurring of borders between parties at the governance level and the intertwining of relations (Jessop, 1995; Rhodes, 1996); an increased need for cooperation, cross-sector policies (O'Connor, 2009; Potts and Cunningham, 2008; Throsby, 2008); the deinstitutionalization of public and private sector partnerships (Lange, 2009); and the increasing significance of the mediating institutions (Costa et al., 2008), etc. It has been argued that CI is creating new (network-based) forms of governance arrangements (Lange, 2008; Kalandides, 2007).

The third issue concerns the beneficiaries of CI policies. In terms of supporting interaction, we may raise the question of which kinds of actors are addressed via CI policies: whose practices are expected to change, and in addition, whether the policy instruments force the actors to cooperate with each other. It is recognized that creative activities often take place in clusters (Porter, 1998; Porter and Stern, 2001) that enable spaces of intensive collaboration. The importance of CI clusters has been seen in their highly interdependent nature, which cultivates urban density and supports the building of healthy communities (Shoales, 2006). The recent studies on CI (Foord, 2008; Evans, 2009) also reveal the increasing importance of cluster development in CI supporting strategies. The discussions about supporting CI have also highlighted that CI push us towards a rethink of the industries, as their organizational model is the network interaction (Hartley, 2005) of micro and small producers rather than the supply chain hierarchy of Fordist industries (Borg and Russo, 2006), and their production model is strongly influenced by user-created content (OECD, 2007). This illuminates the importance of demand-side instruments aside from the supply-side measures in supporting CI. This means that the target group of CI policy is not defined using $\mathrm{CI}$ sector representatives, but is addressed to representatives of other fields, including citizens and the wider public.

We may conclude that CI policies are connected with the design of several diffperent social interaction mechanisms.
Therefore we may raise the following central research question for our study: Have the three Baltic capitals introduced interaction mechanisms in their CI policies that i) support the diffusion of CI knowledge and practices, and ii) facilitate the acceptance of CI policies? If so, what kinds of mechanisms are they?

\section{Creative industries in the capitals of the Baltic States: The context of $\mathrm{Cl}$ policies}

Tallinn, Riga and Vilnius are 'newcomers' in terms of CI policies. The collapse of the Soviet system at the beginning of the 1990s called for substantial changes in all fields, including cultural policy. The introduction of the "Western" concept of CI into the cities of the Baltic States coincided with a period when the market economy was just starting to function in these cities. This makes the situation for developing CI policy in CEE countries radically different from that for Western developed countries. The following peculiarities of the socio-economic background can be considered most important.

Firstly, as Jürisson (2007) has argued, the conflation of market- and consumer-oriented CI with a traditionally elitist cultural policy created a rather conflicting mix. In all post-socialist countries, the cultural sector has initially been perceived from the view of "expenditures on culture" and not from the perspective that the cultural or creative field can generate profit (Primorac, 2006). In the course of time, this kind of attitude changed along with the rise in the importance of making money - this has taken place at different speeds in different spheres of culture ${ }^{1}$.

Secondly, the social context of the "transitional" markets of post-socialist countries differs radically from the social context from which the notion of the CI originated (TomićKoludrović and Petrić, 2005). During the 1990s, developed countries faced the 'second-modernity' (Beck, 1986), which was marked by an increase in post-traditional organizational forms and post-materialist values, and which also paved the way for the emergence of creative industries. At the same time, trends in post-socialist countries can be described according to Inglehart's (2000) classification, as using "survival values". We have to agree with Tomić-Koludrović and Petrić (2005) that despite the development towards individualism, it was certainly not individualization in the sense of post-modernism.

Thirdly, suitable administrative structures for supporting such a new type of integrative development were generally missing in post-socialist countries. The structures in these countries were established for supporting culture via public funding and not for the development of cultural entrepreneurship (Jürisson, 2007). Regarding support measures for entrepreneurship, generally these did not take account of the peculiarities of creative/cultural entrepreneurship.

Fourthly, since the secondary sector (i.e. industry) dominated the economies of these countries during the socialist period, the transformation of industrial urban space in the early 1990s was generally more topical than in the cities of highly-developed market economies (i.e. there was a delayed transition to a services economy). This opened the potential for CI to join the processes of transforming the

\footnotetext{
${ }^{1}$ As the findings of the study, carried out in mid-1990s in Tallinn, Riga and Vilnius and exploring the new industries, indicated (see Cooke et al. (2003) for more details), the level of adopting market economy principles among the cultural enterprises and institutions varied to a great extent (e.g. advertising agencies and architectural bureaus were at the forefront).
} 
urban environment. The extent that this has been realized in post-socialist countries is another matter (Tafel-Viia et al., 2014).

In all of these cities - Tallinn, Riga and Vilnius - the impetus for introducing the CI concept and related policies, in particular, came via a British Council initiative. The efforts to disseminate the CI ideology landed on fertile ground, as cultural policy officials saw new (financial) opportunities through developing CI (Lassur et al., 2010). Initially, the concept of CI made its way to the national policy level and was further transferred to local level programs. Although there are other important factors, which have influenced the development of CI in the cities (e.g. Nordic influence in the case of Tallinn), this kind of top-down policy transfer mechanism has been the central driving force in the emergence of CI policies (Lassur et al., 2010). Certain policy instruments (e.g. strategy document in Latvia, support for incubators and creative centres in Estonia and Lithuania, etc.) for supporting CI have also been developed at the national level; nevertheless, regarding specific actions, the cities themselves have been more active.

All three capitals in the Baltic States have followed an approach to CI adopted at the national level that is an adaptation of the British definition of CI: "The creative industries are those industries which have their origin in individual creativity, skill and talent and which have a potential for wealth and job creation through the generation and exploitation of intellectual property" (CITF, 1998). Still, some important differences can be recognized. Estonia made some minor changes to the British definition by adding a clause about 'collective creativity', in addition to the 'individual' in the definition. In terms of the sub-sectors involved, then only a very limited part of the IT sector is included - entertainment IT (the production of computer games, interactive games, etc.). Latvia and Lithuania encompass a much broader spectrum of the IT sector. Vilnius uses the broadest definition of CI and includes also tourism, sport and other cultural activities. Still, sport and related activities are left out of the mapping studies and in calculations of the economic contribution of CI (Lietuvos Kūrybinès ir Kūlturinès Industrijos, 2009). Thus, Vilnius has defined the concept of CI more loosely and included more sub-sectors, compared to Tallinn and Riga. This indicates that Vilnius aspires to integrate a greater variety of spheres under the development of CI or, the other way round, develop CI via various spheres of life. The addition made by Estonia reflects the need to strengthen interaction within the CI sector, which is important in terms of social innovation.

\section{Methods of data collection and analysis}

The research team which developed the methodology for this study and carried out the analysis was led by the authors. The study encompassed, in addition to the three Baltic capitals (Tallinn, Riga and Vilnius) the following European cities: Helsinki, Oslo, Stockholm, Amsterdam, Barcelona, Berlin, Birmingham and Warsaw. The study was designed to examine the development of CI policies in these cities. Data were collected using a qualitative, structured and semi-open questionnaire. The questionnaire was completed by local researchers in each of the 11 cities, who interviewed the local policy-makers and sector representatives to receive answers to the questions. This process assured that the most relevant and up-to-date information was being used.
The questionnaire consisted of 37 questions divided into four sections:

1. general architecture of support;

2. measures supporting the development of CI;

3. the criteria behind strategic choices in CI policy; and

4. background statistical data.

Cultural policy instruments and supporting measures were excluded for this study. About half of the questions were open-ended, and the remainder had a finite set of predetermined answers. The questionnaire also contained ranking type questions where a 10-point scale was used.

We analysed the data by modifying constant comparative methods (Strauss, 1987; Strauss and Corbin, 1990), which allowed us to develop coding criteria enabling a categorisation of the characteristics of both topics and cities. We implemented an open coding method, meaning that we broke down, examined, compared, conceptualized and categorized the data (Strauss and Corbin, 1990) gathered with the questionnaires. The final coding scheme emerged from several category redefinitions and recoding. Three of the authors of this article were involved in the coding process in order to increase the reliability of coding and categorisation.

After coding all the data (city questionnaires), we moved forward with the analysis using a text expansion strategy to find illustrative texts for the codes and categories (Laherand, 2008). This iterative process was needed to avoid interpretation mistakes in generalising the results of the analysis. The results of the analysis made by the research team were checked with each of the cities several times. In the first phase of analysis, the research team divided the cities into two groups based on the different stages of the development of their CI policies:

1. cities with more established CI policies (WesternEuropean and Nordic cities); and

2. cities as 'newcomers', such as post-socialist cities including Tallinn, Riga and Vilnius.

The first outcomes of the analysis were sent back to the cities' researchers and officials in order to obtain confirmation from them that the results were interpreted correctly. The findings of the analysis were discussed during several interactive workshops among city officials and other CI policy stakeholders to obtain wider reflections. Based on the feedback and discussions, the findings were specified and summarized by the research team members.

In the following section we concentrate on identifying the extent to which the CI policies of Tallinn, Riga and Vilnius contain interaction mechanisms that support the diffusion of CI- related knowledge and, on the other hand, facilitate the adoption of CI policies by various actors in society. The findings reflect each city's policy and do not encompass regional and national policies that may also apply to the cities.

\section{Cl policies of Tallinn, Riga and Vilnius in the context of international comparison}

The findings of the study are presented in three parts. Firstly, we explore the focus of the CI policies in the three cities. Thereupon, we describe how the organizational structure of support in these cities supports the development and adoption of CI policy practices. And thirdly, we explore the changes related to policy instruments in force in the three cities. 


\subsection{The focus of $\mathrm{Cl}$ policies}

When examining the focus of CI policy as written into the policy documents and perceived by the city representatives themselves, two issues are taken into focus: the extent of interaction between CI and other fields at the policy document level, and second, how widely or narrowly CI is understood in terms of the approach and aims set for the CI policy. In the study, the cities were asked to describe the main strategic documents that currently support and develop CI in their city, and to assess the overall focus and approach of their CI policy (see the questions in Table 1).

In all three cities, CIs are included in the city's general strategy and/or long-term development plan. In the case of Tallinn, this means that the development of CI is included in the general strategy document Strategy Tallinn 2025 (from 2004) and the Development Plan for Tallinn 2009-2027. The development of CI is also included in the Tallinn Innovation Strategy (enacted in 2008) and the Tallinn Old Town Development Plan 2008-2013 (enacted in 2008). Regarding Riga, the development of $\mathrm{CI}$ is written into the "Riga city longterm development strategy 2025" (followed by the "Riga city development program 2006-2012"). Riga has also included the development of CI in its cultural policy document: "Riga city cultural policy". Another important document to mention is the "Agreement of support for Creative Industries - Riga City Council and Ministry of Culture protocol of intentions", which is directly aimed at developing CI. With respect to Vilnius, the development of CI is included in the strategy document "Strategic Vilnius City 2002-2011 Plan". Another important document is "The Creative Incubators Financing Programme", that directly focuses on stimulating the CI sector. CI is also mentioned in the "Vilnius Master Plan 2015 - urban city development strategy".

\begin{tabular}{|l}
\hline Questions \\
\hline a) $\begin{array}{l}\text { Please provide a list of the strategic documents in force (strategies, action plans, etc.) that are aimed at } \\
\text { supporting CI or include activities related to CI. Please start with the most relevant. }\end{array}$ \\
\hline b) Please provide a short overview (nature and main goals) of the documents listed. \\
\hline c) Please indicate the focus of CI policy on the given scale (economic, spatial, social / inward - outward) \\
\hline d) \\
Please describe the overall aim of your city's CI policy. \\
e) $\begin{array}{l}\text { Please indicate which overall approach to supporting CI dominates in your city, selecting between the } \\
\text { following alternatives (sector-based, cluster based, CI sector is supported as a whole). }\end{array}$
\end{tabular}

Tab. 1: Questions related to the focus of CI policy

Source: "Creative Metropoles study: Situation analysis of 11 cities" (CM, 2010); compiled by the authors

Comparing the three cities then, Tallinn in particular has chosen to include the development of CI in various strategic documents. The inclusion of $\mathrm{CI}$ in the innovation strategy indicates that Tallinn is following rather recent trends in CI policies that link the development of CI with economic and innovation policies. Tallinn, however, has no dedicated document for the development of the CI sector. Vilnius has primarily included CI in documents that relate to wider urban development. In the form of the incubator financing programme, Vilnius also has a policy document directly supporting the CI sector. As opposed to Tallinn and Vilnius, Riga is developing CI more within the framework of its cultural policy. Therefore, we can notice differences in the policy practices of each of the cities: compared to Riga, Tallinn and Vilnius have linked the development of CI more broadly with other fields. Despite the fact that the mere inclusion of the development of CI in policy documents does not directly indicate changes in policy practices, we may still argue that designating CI among the development priorities of the cities can be considered as a relatively large achievement.

Analyzing the aim and approach of CI policies in the three cities, we start from the question of the overall aim of the city's CI policy. Tallinn responded as follows:

"... different documents and activities derive towards two main focuses: 1) attractive living, working and visiting environment - meaning the development of space and supporting of vivid cultural life in the city: aimed at attracting and inspiring for locals, visitors, investors and talents; 2) /.../ to pay more attention also to creative entrepreneurship /.../." (Tallinn)
This aim contains two main spheres - spatial and economic - present in Tallinn's CI policy. It also indicates that CI policy has both an inward and outward dimension: the city environment has to inspire locals and also attract visitors and investors. Further analysis of the policy documents enables us to explain the aim of Tallinn's CI policy in more detail. One group of objectives in different strategic documents for developing CI is linked with the tourism sector. By using the term 'experience economy' in the document, "Strategy Tallinn 2025", CI is understood as a broad sector including all actors and activities which provide emotions (i.e. culture, sport, leisure time activities, etc.). In other policy documents the term 'creative industries' as understood in the British approach is used.

In the Development Plan of Tallinn 2009-2027 one can find objectives explicitly focusing on developing the CI sector: "Opportunities for creators to introduce their creation and others for partaking in artistic experiences" (Development..., 2008). The inclusion of CI in the Tallinn Innovation Strategy (2008) broadens the framework in which $\mathrm{CI}$ is to develop. This strategy focuses on CI's ability to create an inspiring and attractive living and working environment (attracting talents and investments); therefore, emphasizing the spatial dimension. On the other hand, the creative industries are explained in the context of "/.../ having a major influence on other economic activities" (Tallinn..., 2008), which illuminates the economic aspiration in developing $\mathrm{CI}$ and emphasizes linkages with other economic sectors. The inclusion of CI in the innovation strategy also refers to the integration between cultural, entrepreneurial and innovation fields. The objectives related to the development 
of CI in the Tallinn Old Town Development Plan 2008-2013 (Tallinna..., 2008) are primarily associated with tourism and business development in this area, but also CI's importance in developing an attractive environment. Thus, we see again an emphasis on the spatial in the policy document.

Riga's response to the question about the overall aim of the city's CI policy was as follows:

"... to maximize economic benefit from the cultural industries concentrated in the city and from creative potential." (Riga)

This kind of aim indicates the rather clear economic focus of the city's CI policy. The analysis of Riga's policy documents, however, enables us to somewhat broaden the policy focus. In the "Riga city long-term development strategy until 2025", Riga has set up the creative economy as one of the priorities in the development of the city. The policy documents oriented explicitly towards the development of the CI sector address primarily the economic sphere: the priority is to maximize the economic benefit from the city's cultural and creative industries. The spatial focus is also addressed by linking the development of the city's infrastructure, cultural processes and creative districts to the development of CI. The development of the city space is considered important for both locals and tourists, which indicates that inward and outward dimensions are both addressed in the documents. According to explanations by representatives of the city, the spatial orientation is considerably less important compared to attaching value to maximizing the economic benefits from the CI sector.

Vilnius described the overall aim of the city's CI policy as follows:

"/.../ one of the main CI developments /.../ should be aimed at those CI sectors that are directly related to tourist arrival activities, namely related to the export of CI products and services. /.../ However, another very important CI function of the city is to stimulate public creativity and civil activity, participating in Vilnius city as well as international cultural projects to ensure harmonious urban city development, attracting the local community as well as the guests of the city."

Based on this response, Vilnius has set rather a broad goal for its CI policy. It contains building linkages with other sectors - with the tourism sector in particular. Furthermore, it includes the aspiration of including the wider public and not merely the actors in the CI sector. Thus, the policy focus is not limited to enhancing the business capacity of the CI sector, but the participation and social interaction of the wider public are also seen as part of CI policy. Further analysis of the policy documents confirm that one group of activities in the CI policy is linked to the tourism sector. The development of the entertainment and leisure sector is also seen as part of the development of CI. The city's main strategy document "Strategic Vilnius City 2002-2011 Plan", makes use of the concept of a creative city and has set up four strategic development priorities: international competitiveness, new economy, progressive society and communication system. This indicates a rather broad focus, including the stimulation of public creativity and citizen participation as important CI-related activities. The CIsector specific document "The Creative incubators financing programme" has again a clear economic focus: it is intended to stimulate artists that are starting businesses and creative businesses by offering reduced rent, business consulting and public relations services.

At the level of CI policy goals, we see that of all the three cities, Vilnius is making the strongest attempt to follow an all-embracing approach in developing CI: economic, spatial and social spheres are all visible on the level of overall focus of its CI policy. Tallinn also has set a rather broad focus for its CI policy, especially in terms of linking CI development with innovation enhancement. Riga tends to emphasize an economic focus in developing CI, which is the narrowest approach compared to the other two cities.

\subsection{Organizational support for $\mathrm{Cl}$ policy in Tallinn, Riga and Vilnius}

In this section we examine the form of support structures for CI policy in Tallinn, Riga and Vilnius. The question is whether the organizational structure of support is based on cooperation and how it enhances (new) forms of collaboration between different structures and institutions (see the questions in Table 2).

Based on the responses, the situation of the support architecture in the three capitals of the Baltic States can be described as follows:

- In Tallinn there are principally three departments involved: the Business Development Department, the Cultural Department and the City Office Development Bureau. The responsibility for supporting CI is mainly divided between the business development and cultural department who provide grants or other forms of support

\begin{tabular}{|l|l|}
\hline Questions \\
\hline a) & $\begin{array}{l}\text { Please describe the division of support architecture between state, regional and local (your city) level in } \\
\text { supporting CI. }\end{array}$ \\
\hline b) & Please describe the explicit role (the extent of activities) the city has in developing and supporting CIs. \\
\hline c) & $\begin{array}{l}\text { Please describe the organizational structure of support for CI. Please name and describe the structural units } \\
\text { of the city, special organizations and actors responsible for supporting (implementing) the CI on the city level. }\end{array}$ \\
\hline d) & $\begin{array}{l}\text { Please describe the cooperation model with businesses and the third sector: the division of work/tasks } \\
\text { between the public sector, business sector and third sector. }\end{array}$ \\
\hline e) & Please describe the situation in international cooperation in the field of CI development. \\
\hline f) & Please indicate who initiates the goals for CI policies in your city. (List of five possible variants was given.) \\
\hline
\end{tabular}

Tab. 2: Questions related to the organizational structure of support for CI policy

Source: "Creative Metropoles study: Situation analysis of 11 cities" (CM, 2010); compiled by the authors 
and services. The City Office Development Bureau is responsible of compiling strategies and other city development documents. The cooperation with the third sector has been gradually getting stronger - especially the cooperation with sector-based organizations (e.g. professional unions). Cooperation with the third sector has also been developing due to increasing grass-roots activities within the CI sector (Lassur et al., 2010);

- In Riga, the Culture Department is the leading actor in implementing and developing CI support policy and two other departments are also involved, the City Development Department and the Business Coordination Centre. There is no dedicated unit for the coordination of CI-related activities; however, the Culture Department aims to involve the aforementioned departments in coordinated actions. The leading role of the Culture Department also explains why CI has been included primarily in cultural development documents. Regarding cooperation with the business and third sector, Riga has claimed that each of the aforementioned City council departments has developed its own method of cooperation. Still, cooperation with non-government organizations can be characterized as rather reactive to requests from different sectors, expecting the private and third sectors to come up with their own initiatives.

- Vilnius has claimed that there are several departments involved in developing CI, including: the Property Department, which includes business activities, the Urban Planning Department and the Culture and Education Department, which also has a tourism development section. There are various administrative units involved in supporting CI, but there is still no indication of how the coordination of activities between such departments takes place. In terms of cooperation between the city and the business and third sectors, this takes place solely in the context of certain topics and issues, such as specific events and activities.

According to the SI approach, for interaction processes the amount of various actors involved plays a critical role. Therefore we may assume that the greater amount of different departments involved in policy development and implementation, is the first necessary condition for cooperation to take place. SI emphasizes the importance of shared understandings, such that the existence of interaction mechanisms between different actors - between different departments in our case - plays also a critical role. In light of the involvement of different actors in policy development and implementation processes, Vilnius and Tallinn perform slightly better than Riga. Still, none of the three cities indicated any new cooperation patterns or forms, or the creation of any new governance arrangements. Levels of interaction with various stakeholders have also remained rather modest in all three cities.

\subsection{Cl policy instruments in Tallinn, Riga and Vilnius}

In this study the cities were asked to single out the ten most important measures that support and develop CI.

Q: Please name the 10 most relevant measures (grant schemes, support tools, investments, regulations, etc.) in force in your city.

The cities were also given a list of four arguments to consider when selecting the measures. The measure was considered important if: (1) it has an impact on a large number of CI actors; (2) it is directed at developing the prioritized CI sector or cluster; (3) it is financially significant; and (4) it has a broad impact. In the case of each measure, the cities were asked to answer seven questions to describe the measure (see Tab. 3).

All three Baltic capitals indicated less than 10 measures, which show that their CI policies are at a developmental stage. Furthermore, the majority of the measures the cities singled out are not specifically tailor-made measures for developing the CI sector, but are measures that also apply to other sectors (e.g. startup aid for starting companies, including creative enterprises) or existing measures supporting the cultural sector that are now also starting to be seen as measures that support the development of CI (e.g. support for festivals). In the analysis, we focused on identifying whether interaction is supported through applying these measures and what kind of interaction. By coding the measures using a scale where $1=$ no orientation to cooperation and $4=$ orientation to wider social interaction, we were able to divide the measures for the three cities into four groups. The first group contains measures that are targetted at enhancing the CI sector's own capacity, but contains no interaction within the CI sector or with other sectors. The second group consists of measures focusing on supporting cooperation within the CI sector. The third group

\begin{tabular}{|ll|}
\hline Questions \\
\hline a) Title of the measure. \\
\hline b) Type of measure (based on the given classification). \\
\hline c) $\quad \begin{array}{l}\text { Purpose of the measure. Please describe the main goals and rationale (analytical reasoning why this measu- } \\
\text { re is being created). }\end{array}$ \\
\hline d) Start date and expected end / no end date planned. \\
\hline e) Target groups. Please indicate which group(s) the measures are targeted at. \\
\hline f) $\quad$ In what form is funding provided? \\
\hline g) $\quad \begin{array}{l}\text { Please provide the annual city funding for the measure and total city funding of the measure, if applicable } \\
\text { (e.g. the total investment for the city district for } 3 \text { years). }\end{array}$ \\
\hline
\end{tabular}

Tab. 3: Questions related to measures supporting and developing CI in the city

Source: "Creative Metropoles study: Situation analysis of 11 cities" (CM, 2010); compiled by the authors 
of measures relate to enhancing cooperation between the CI sector and other sector(s). This group also includes measures where CI is developed through the development of other sectors. The fourth group of measures encompasses activities supporting wider interaction or involvement. The measures in the fourth group may also contain forms of cooperation from the second and third group or some combinations of these forms (see Tab. 4).

As can be seen from Table 4, Tallinn has placed emphasis on two directions: enhancing the capacity of the CI sector and supporting broader involvement. Two measures in particular - "Start-up aid for new business" and "Support for cultural activities by non-profit organizations" - are targetted to improve the economic performance of CI sector actors. The "Action of Culture" award has established the aim of valuing creative professionals and/or events. Regarding the other end of the scale - supporting wider interaction - within the framework of the reconstruction of the Culture Cauldron in Tallinn, educational activities in cooperation with the Energy Science Centre (museum, science and discovery centre located in Tallinn) are foreseen (Kultuurikatel, 2009). A plan exists to embed the centre in the local community of the city and to involve the general public; however, currently this plan is rather poorly expressed. Two more measures "Support for citywide cultural events" and "Compilation and exhibition of art collections" - are both intended to stimulate demand for CI sector products and services: the first measure is targetted at stimulating demand in the wider public, and the second fosters the use of CI services by the public sector.
It is important to highlight the Tallinn Creative Incubator, as it has been tailor-made for the development of the CI sector. Launched in 2009, it represents a new element in the CI support system in Tallinn. Besides supporting the economic capacity of CI sector actors, the shared space also stimulates cooperation within the sector.

In Riga, the majority of the measures belong to the third and fourth group, targetted at supporting cooperation with other sectors and stimulating wider social involvement. As in Tallinn, Riga supports festivals and develops the "Riga Art Space" (similar to the Culture Cauldron in Tallinn), which is seen as a multifunctional contemporary art space. The "Future City Game" measure is directly oriented towards developing and strengthening linkages between the arts, culture and entrepreneurship. It is aimed at producing innovative ideas for the city's development and stimulating the participation of actors from different spheres of life (CI sector, real estate market, citizens, etc.) in improving their living environment. Compared to the other two cities, Riga has more measures related to supporting cooperation between CI and other sectors. The cooperation pattern here, however, is rather one-sided and relates to developing CI in the context of the exposure of cultural heritage and the renovation of infrastructure.

Vilnius implements the most measures that support wider social interaction. As with Tallinn, Vilnius supports the enhancement of public demand for CI through supporting citizen access to different cultural events ("Financing festivals, cultural events and shows"), and stimulates the

\begin{tabular}{|c|c|c|c|c|}
\hline & $\begin{array}{c}1 \\
\text { CI sector enhancement } \\
\text { (no orientation for } \\
\text { cooperation) }\end{array}$ & $\begin{array}{c}2 \\
\begin{array}{c}\text { Cooperation within CI } \\
\text { sector }\end{array}\end{array}$ & $\begin{array}{c}3 \\
\begin{array}{c}\text { Cooperation between CI } \\
\text { and other sector(s) }\end{array}\end{array}$ & $\begin{array}{c}4 \\
\begin{array}{l}\text { Wider social interaction/ } \\
\text { involvement }\end{array}\end{array}$ \\
\hline Tallinn & $\begin{array}{l}\text { - Award "Action of Culture" } \\
\text { - Start-up aid to support } \\
\text { new businesses (incl. creative } \\
\text { companies, individuals) } \\
\text { - Support for cultural activities } \\
\text { by non-profit organizations }\end{array}$ & $\begin{array}{l}\text { - Tallinn Creative Incubator } \\
\text { - Co-financing of cluster } \\
\text { projects }\end{array}$ & - Neat Old House Project & $\begin{array}{l}\text { - Reconstruction of Culture } \\
\text { Cauldron and development } \\
\text { of the organization of the } \\
\text { Culture Cauldron } \\
\text { - Support for citywide } \\
\text { cultural events } \\
\text { - Compilation and exhibition } \\
\text { of art collections }\end{array}$ \\
\hline Riga & • Grant program „Take-Off“ & & $\begin{array}{l}\text { - Public support for } \\
\text { renovating architectural } \\
\text { heritage objects } \\
\text { - Infrastructure improvement } \\
\text { in the Spikeri district }\end{array}$ & $\begin{array}{l}\text { - Riga Art Space } \\
\text { - Target program to support } \\
\text { festivals } \\
\text { - Future City Game • }\end{array}$ \\
\hline Vilnius & $\begin{array}{l}\text { - Support for separate CI } \\
\text { sectors by financing municipal } \\
\text { institutions operating in the } \\
\text { field of CI (theatres, cinemas, } \\
\text { orchestras, choirs, cultural } \\
\text { centers, galleries, event } \\
\text { organizers, etc.) } \\
\text { - Enterprise training } \\
\text { measures }\end{array}$ & $\begin{array}{l}\text { - CI incubators in Vilnius } \\
\text { - Funding for participating } \\
\text { in international cultural } \\
\text { projects }\end{array}$ & $\begin{array}{lr}\text { - Tourism development } \\
\text { (tourism r development } \\
\text { strategies, marketing tools for } \\
\text { city identity, image, tourism) }\end{array}$ & $\begin{array}{l}\text { - Financing festivals, cultural } \\
\text { events and shows } \\
\text { - Municipal expenditures } \\
\text { on CI services and products } \\
\text { (advertising, architects, } \\
\text { media and other services) } \\
\text { - Planning cultural city } \\
\text { districts and investing in } \\
\text { their development } \\
\text { - Support for cultural projects } \\
\text { and creative educational } \\
\text { projects }\end{array}$ \\
\hline
\end{tabular}

Tab. 4: Division of the most important CI policy instruments of the three cities based on their orientation to supporting cooperation/interaction. Source: "Creative Metropoles study: Situation analysis of 11 cities" (CM, 2010); compiled by the authors 
need for professional CI services and products among the general public that is within the parameters of the measure "Cultural project and creative educational project support". The measure "Municipal expenditures on CI services and products", has been established in order to stimulate CI activities that have the highest level of public and social demand. Here the public sector uses a direct instrument in order to draw wider public attention to CI and increase the awareness of the capacities CI have to offer. Also like Tallinn, Vilnius has paid attention to enhancing the capacity of the CI sector and stimulating cooperation within the sector. Vilnius has a tailor-made measure for the CI sector (a CI incubator) and also finances participation in international cultural projects in order to stimulate shared experiences in the CI sector internationally, and increase awareness of Vilnius's CI abroad. Regarding cooperation with other sectors, Vilnius supports the linkages between $\mathrm{CI}$ and the tourism sector.

To sum up, the majority of the measures in the three cities are targetted at enhancing wider social interaction and involvement, and at the very least the measures are targetted at supporting cooperation within the CI sector as well as with other sectors. The rather high importance of demandside measures - those supporting wider social interaction, which include the most important measures in all three cities - is in line with recent CI policy trends. Nevertheless, as the majority of these measures have already been in use to support the cultural sector for some time, and are now being viewed as also appropriate for the development of CI (e.g. support for festivals), it is questionable how contemporary these measures actually are. What seems clear is that the beneficiaries from these measures are not limited to CI sector actors, but also encompass citizens and the general public. At the same time, cluster development, which has also been highlighted as a recent important direction in CI policy development, is practically missing in all three cities. The comparison of the three cities indicates that the spectrum of measures in Vilnius and Tallinn is more diverse than in Riga, and that although Vilnius has implemented more measures that support wider social interaction, the complex of measures in these two cities is rather similar.

\section{Conclusions}

This article aimed to explore the transformation of urban policy emerging from the development of CI policiesrelated initiatives in Tallinn, Riga and Vilnius. Due to the domination of top-down policy transformation, we used the concept of social innovation to highlight the importance of facilitating the adoption processes in the development of CI policies. We examined whether and which types of interaction mechanisms can be identified within CI policies of Baltic States capitals from three perspectives: in terms of the aims described in the policy documents; the structure of organizational support; and the actual measures.

All in all, the findings of the study enable us to conclude that all three cities seem rather active in developing CI, but from the perspective of supporting the implementation of CI policies and facilitate the adoption of related new practices, the situation is somewhat vague. We drew three significant conclusions:

- First: the interaction mechanisms are presented differently at the level of strategies, the structure of organizational support, and CI policy measures. In terms of the aims described in the policy documents, all three cities have included the topic of CI in different policy documents, although the scope of the aims and the level of integration with other policy documents vary. Vilnius has made the strongest attempt to follow an all-embracing approach at the level of an overall policy focus by encompassing economic, spatial and social spheres into the development of CI. Tallinn also has taken a rather broad focus, with the emphasis on the economic and spatial dimensions. Riga has taken the narrowest approach, seeing the development of CI primarily in the context of economic benefit and developing CI as a sector-based policy.

In terms of the organizational support structure, there is no reflection of any interaction mechanisms between different policy actors involved in developing CI, and this applies to all three cities. There is no indication of the creation of a new type of organisational arrangement that could support cooperation between different units or departments. In terms of actual measures, there are only some single instruments in the cities especially designed to support the development of CI. As there are practically no signs of interaction at the level of the support structure and instruments by means of which CI policy is to be implemented, we may conclude that there are only weak isolated signals about the transformation of urban policy resulting from the introduction and diffusion of the concept of CI in Tallinn, Riga and Vilnius. CI policy development predominantly takes place in the form of the continuation of cultural, entrepreneurship and/or innovation policy practices from previous periods, so the CI policy in the Baltics is predominantly "old wine in a new bottle".

- Second: none of the three cities has made specific efforts to facilitate the acceptance of CI- related policy initiatives among the beneficiaries of the policies: building networks, arenas for knowledge exchange, and other interaction mechanisms. All reported weak cooperation with the business and third sector in the field of CI, only a few measures support cooperation between the $\mathrm{CI}$ and other sectors. CI measures are not targetted at involving actors from other sectors, which can be seen as an obstacle for the wider diffusion of CI knowledge and practices. Integration between CI and other spheres exists mainly at the policy document level.

- Third: we can observe contradictions between policy aims and the structures and instruments chosen. Vilnius's CI policy practices seem to be the most coherent. Vilnius has taken the most comprehensive approach to the development of CI at all levels: it has included it in various policy documents, it has involved several city departments and it has the greatest number of measures that are targetted towards wider social interaction. In the case of Tallinn and Riga, we can see certain discrepancies between the aims and the structures and instruments. Although Tallinn has taken a rather broad approach by linking CI development with innovation policy and including the development of CI in various documents and dividing tasks between several departments, the measures are mostly targetted at enhancing CI sector capacity, and not supporting the linkages between other sectors and actors. Riga has chosen the most focused approach by concentrating on raising the economic benefit from CI, although the main support structure is the cultural department, which explains why the majority of the CI policy measures are related to the development of cultural heritage and festivals. 
Thus, despite the application of similar top-down CI policies, location-specific factors do influence the cities in their choice of different development trajectories, which also supports the path-dependency argument in explaining the development of CI policy practices. The three cities are similar in terms of having certain difficulties in adapting organizational support structures and policy measures to support CI development. All tried to adapt their existing cultural and economic policy measures and organizational structures to suit CI policy, rather than focusing on introducing new instruments and governance forms that are based on interaction and involvement. These findings reveal that the introduction of the CI concept in the Baltic States capitals has still had a rather slight influence on their urban policy transformation. This reaffirms the argument that cities with a post-socialist background find it difficult to develop CI policies because suitable administrative structures for supporting such new integrative developments are missing.

To summarize, this study has shown that all three Baltic capitals have perceived the opportunities inherent in CI development - and have included the development of CI among their strategic aims and in development documents. The results of the study reveal, however, that the phenomena of such kinds of policy transformations that one can find in Western cities where CI policy development has focused on reshaping the city's images, renewing economic policy principles and integrating cultural fields with other sectors, are rather weakly present in the Baltic capitals that have post-socialist backgrounds. In the Baltic States, we may rather notice a continuation of the policy practices of previous periods. The 'traditional' structures and instruments dominate without new policy practices being developed, even though in isolated cases we can see the adaptation of existing schemes to meet the needs resulting from the peculiarities of CI (e.g. the Creative Incubator in Tallinn). The lack of particular interaction mechanisms within the support structures and instruments for supporting CI hinders, or at least slows down, potential interaction among the different policy actors and stakeholders. Therefore, it is complicated to predict the deeper changes in meanings, everyday practices and social structures that are seen as the main characteristics of change by SI theorists. All in all, at present, we can acknowledge the fact that the introduction of the concept of CI in the Baltic capitals has brought along only minimal transformation of urban policy. As the transformation of urban policy is a complex process, there is a need to further explore the changes taking place in time to evaluate the depth of possible changes.

\section{Acknowledgements}

The authors would like to express gratitude to their research partners in the Creative Metropoles project and to the municipal partners from the 11 cities involved, all of whom contributed and shared their experiences. The authors would also like to sincerely thank the referees for their valuable comments and greatly appreciate their recommendations.

\section{References:}

AGREEMENT OF SUPPORT FOR CREATIVE INDUSTRIES (2008): Riga City Council and Ministry of Culture protocol of intentions.

BALDUCCI, A. (2004): Creative Governance in Dynamic City Regions. DISP, 158: 21-26.
BECK, U. (1986): Risikogesellschaft. Auf dem Weg in eine andere Moderne. Frankfurt am Main, Suhrkamp.

BORG, VAN DER J., RUSSO, A.P. (2006): The impacts of culture on the Economic development of Cities. Erasmus University Rotterdam, European Institute for Comparative Urban Research.

BRAMHAM, P., SPINK, J. (2009): Leeds - Becoming the Postmodern City. In: Bramham, P., Wagg, S. [eds.]: Sport, Leisure and Culture in the Postmodern City (pp. 9-32). England: Achgate.

COSTA, P., MAGALHĂES, M., VASCONCELOS, B., SUGAHARA, G. (2008): On 'creative cities' governance models: a comparative approach. The Service Industries Journal, 28(3): 393-413.

COOKE, P., TERK, E., KARNITE, R., BLAGNYS, G. (2003): Urban Transformation in the Capitals of the Baltic States: Innovation, Culture and Finance.” In: Bridge, G., Watson, S. [eds.]: A Companion to the City (pp. 237-247). Oxford, Blackwell Publishing Ltd.

CM (2010): Creative Metropoles - Public Policies and Instruments in Support of Creative Industries. INTERREG IVC project's research report. Tallinn, Tallinn University, Estonian Institute for Futures Studies.

CITF (1998): Creative Industries Mapping Document. Creative Industries Task Force [online]. [cit. 26.10.2008]. http://www.culture.gov.uk/global/publications/ archive_1998/Creative_Industries_Mapping_ Document_1998

DEVELOPMENT PLAN OF TALLINN 2009-2027 (2008): Tallinna Linnavalitsus [online]. [cit. 27.10.2010]. Available at: http://www.tallinn.ee/g3230s43281

ENGESTRÖM, Y. (1987): Learning by expanding: An activity-theoretical approach to developmental research. Helsinki, Orienta-Konsulti.

EVANS, G. (2009): Creative Cities, Creative Spaces and Urban Policy. Urban Studies, 46(5-6): 1003-1040.

FLORIDA, R. (2002): The Rise of the Creative Class. And How it's Transforming Work, Leisure, Community and Everyday Life. New York, Basic Books.

FOORD, J. (2008): Strategies for creative industries: and international review. Creative Industries Journal, 1(2): 91-113.

GOPALAKRISHNAN, S., DAMANPOUR, F. (1997): A review of innovation research in economics, sociology and technology management. International Journal of Management Science, 25(1): 15-28.

HARTLEY, J. [ed.]. (2005): Creative industries. Malden, MA \& Oxford, Blackwell.

HEARN, G., ROODHOUSE, S., BLAKEY, J. (2007): From Value chain to value creating ecology. Implications for creative industries development policy. International Journal of Cultural Policy, 13(4): 419-436.

HEISKALA, R. (2007): Social innovations: structural and power perspectives. In: Hämäläinen, T. J., Heiskala, R. [eds.]: Social Innovations, Institutional Change and Economic Performance (pp. 52-79). Cheltenham, Edward Elgar.

HEISKALA， R., HÄMÄLÄINEN, T. J. (2007): Social innovation or hegemonic change? Rapid paradigm change in Finland in the 1980s and 1990s. In: Hämäläinen, T. J., 
Heiskala, R. [eds.]: Social Innovations, Institutional Change and Economic Performance (pp. 80-94). Cheltenham, Edward Elgar.

HESMONDHALGH, D., PRATT, A. C. (2005): Cultural industries and cultural policy. International Journal of Cultural Policy, 11(1): 1-14.

HOWKINS, J. (2002): The Creative Economy. How People Make Money from Ideas. London, Penguin Books.

INGLEHART, R. (2000): Culture and Democracy. In: Harrison, L. E., Huntington, S. P. [eds.]: Culture Matters: How Values Shape Human Progress (pp. 80-97). New York, Basic Books.

JESSOP, B. (1995): The regulation approach, governance and post-Fordism. Economy and Society, 24(3): 307-333.

JÜRISSON, V. (2007): The Creative Economy and Offside in Cultural Policy: An Economies in Transition Perspective. Paper presented to the VII Annual Conference of Estonian Social Sciences, Tartu, 28.-29. November 2007.

KALANDIDES, A. (2007): For a stricter use of the term „gentrification“. Geographies, 13: 158-172.

KULTUURIKATEL (2009): Tallinna Linnavolikogu haridus- ja kultuurikomisjon, 11.03.2009 [online]. [cit. 27.05.2010]. Available at: http://www.tallinnlv.ee/aktalav/ Koosolekud/Dokumendid/pkldok10540.ppt

KUNZMANN, K. R. (2004): An Agenda for Creative Governance in City Regions. DISP, 158: 5-10.

LAHERAND, M.-L. (2008): Kvalitatiivne uurimisviis. Tallinn.

LANDRY, C. (2000): The Creative City: A Toolkit for Urban Innovators. London, Earthscan.

LANDRY, C., GREENE, L., MATARASSO, F., BIANCHINI, F. (2005): Age of the City - Creativity and the city [online]. [cit. 27.10.2010]. Available at: http://www.comedia.org.uk/pages/ pdf/downloads/Age_of_the_City_Creativity_and_the_city.pdf

LANGE, B., PRADEL I MIQUEL, M., GARNIZOV, V. (2010): New governance, new geographic scales, new institutional settings. In: Musterd S., Murie A. [eds.]: Making competitive cities (pp. 306-326). Chichester, J. Wiley and Sons.

LANGE, L. (2008): Accessing markets in creative industries professionalization and social-spatial strategies of culturepreneurs in Berlin. Creative Industries Journal, 1(2): 115-135.

LANGE, L. (2009): Re-scaling governance in Berlin's creative economy. Creative Encounters Working Paper, 39: 3-28.

LASSUR, S., TAFEL-VIIA, K., SUMMATAVET, K., TERK, E. (2010): Intertwining of drivers in formation of new policy focus: case of creative industries in Tallinn. Nordic Journal of Cultural Policy, 1(13): 59-86.

LIETUVOS KURYBINES IR KULTURINES INDUSTRIJOS [Lithuanian Creative and Cultural industries] (2009): Integruotos meno, mokslo, studiju ir verslo nacionalines kopleksines programos.

LODGE, M. (2007): Comparative Public policy. In: Fischer, F., Miller, G., Sidney, M. S. [eds.]: Handbook of Public Policy Analysis: theory, politics and methods (pp. 273-288). Boca Raton, London, New York, CRC Press.

MARCEY, T., MUMFORD, M. D. (2007): Social Innovation: Enhancing Creative Performance Through Causal Analysis. Creativity Research Journal, 19(2-3): 123-140.
MOULAERT, F., MARTINELLI, F., SWYNGEDOUW, E., GONZALES, S. (2005): Towards Alternative Model(s) of Local Innovation. Urban Studies, 42(11): 1969-1990.

MULGAN, G. (2006): The process of social innovation. Innovations: Technology, Governance, Globalization, 1(2): 145-162.

NUSSBAUMER, J., MOULAERT, F. (2004): Integrated area development and social innovation in European cities. City, 8(2): 249-258.

O'CONNOR, J. (2009): Creative industries: a new direction? International Journal of Cultural Policy, 15(4): 387-402.

OECD (2007): Participative Web: User-Created Content (Working Party on the Information Economy), OECD, April 2007 [online]. [cit. 27.10.2008]. Available at: www. oecd.org/dataoecd/57/14/38393115.pdf

PINE, J. II, GILMORE, J. H. (1999): The Experience Economy: Work is theatre \& every business a stage. Cambridge: Harvard Business School Press.

PORTER, M. E. (1998): Clusters and the New Economics of Competition. Harvard Business Review, Nov-Dec: 77-87.

PORTER, M. E., STERN, S. (2001): Innovation: Location Matters. MIT Sloan Management Review, Summer: 28-36.

POTTS, J., CUNNINGHAM, S. (2008): Four models of the creative industries. International Journal of Cultural Policy, 14(3): 233-247.

POTTS, J., CUNNINGHAM, S., HARTLEY, J., ORMEROD, P. (2008): Social network markets: A new definition of the creative industries. Journal of Cultural Economics, 32: 167-185.

PRIMORAC, J. (2006): The position of cultural workers in creative industries: The south-eastern European perspective. Amsterdam, European Cultural Foundation.

RIGA CITY CULTURAL POLICY 2008-2025 (2008) [online]. [cit. 25.10.2009]. Available at: http://zilite.riga.lv/EDC_ portals/GetFile.aspx?id $=1053622 \&$ dbType $=1$

RIGA CITY DEVELOPMENT PROGRAM 2006-2012 (2005) [online]. [cit. 26.10.2009]. Available at: http:// www.rdpad.lv/uploads/rpap/Rigas_ilgtermina_attistibas_ programma_2006.-2015.g.pdf

RIGA CITY LONG-TERM DEVELOPMENT STRATEGY UNTIL 2025 (2005) [online]. [cit. 25.10.2009]. Available at: http://www.rdpad.lv/uploads/rpap/Rigas_ilgtermina attistibas_strategija_2025.g.pdf

RHODES, R. A. W. (1996): The New Governance: Governing without Government. Political Studies, XLIV: 652-667.

SCOTT, W. R. (2001): Institutions and organizations. $2^{\text {nd }}$ ed. Thousand Oaks, CA, Sage Publications.

SHOALES, J. (2006): Alpha clusters: creative innovation in local economies. Economic Development Quarterly, 20(2): 162-177.

STRATEGY TALLINN 2025 [Strateegia Tallinn 2025] (2004): Tallinna Linnavolikogu 10. juuni 2004. a. määrus nr 23.

STRATEGIC VILNIUS CITY 2002-2011 PLAN (2004): with changes made on 2004-02-11 by Vilnius city council (Vilnius city council decision No. 1-228 of 11 February, 2004, concerning changes in Council decision No. 607 of 2002-06-19 "About confirmation of Vilnius city strategic plan for 2002-2011"). 
STRAUSS, A. (1987): Qualitative analysis for Social Scientists. New York, Cambridge University Press.

STRAUSS, A., CORBIN, J. (1990): Basics of Qualitative Research: Grounded Theory, Procedures and Techniques. Newbury Park, CA, Sage.

SUCIU, M.-C. (2009) Creative Economy and Creative Cities. Romanian Journal of Regional Science, 3(1): 83-91.

TAFEL-VIIA, K., VIIA, A., TERK, E., LASSUR, S. (2014): Urban Policies for the Creative Industries: A European Comparison. European Planning Studies, 22(4): 796-815.

TALLINN INNOVATION STRATEGY (2008): Tallinna Linnavalitsus [online]. [cit. 27.10.2010]. Available at: http:/ www.tallinn.ee/eng/Tallinn-Innovation-Strategy-2009-2013

TALLINNA VANALINNA ARENGUKAVA [Tallinn Old Town Development Plan] 2008-2013 (2008): Tallinna Linnakantselei [online]. [cit. 27.10.2010]. Available at: http://www.tallinnlv.ee/aktalav/Eelnoud/Dokumendid/ ddok9910.htm

THE CREATIVE INCUBATORS FINANCING PROGRAMME [online]. [cit. 22.11.2010]. Available at: http://www.vilnius.lt/

THROSBY, D. (2008): Modeling the Cultural Industries. International Journal of Cultural Policy, 14(3): 217-232.

TOMIĆ-KOLUDROVIĆ, I., PETRIĆ, M. (2005): Creative Industries in Transition: Towards a Creative Economy. In: Švob-Dokić, N. [ed.]: The Emerging Creative
Industries in Southeastern Europe (pp. 7-24). Zagreb, Institute for International Relations.

TUOMI, I. (2005): The Future of Learning in the Knowledge Society: Disruptive Changes for Europe by 2020. Background paper prepared for DG JRC/IPTS and DG EAC [online]. [cit. 22.11.2010]. Available at: http://www. meaningprocessing.com/personalPages/tuomi/articles/ TheFutureOfLearningInTheKnowledgeSociety.pdf

TUOMI, I. (2006): The New Meaning Processing Paradigm. In: Compańó, R., Pascu, C., Bianchi, A., Burgelman, J.-C., Barrios, S., Ulbrich, M., Maghiros, I. [eds.]: The Future of the Information Society in Europe: Contributions to the Debate (pp. 197-227). EC JRC, IPT.

TUOMI-GRÖHN, T., ENGESTRÖM, Y., YOUNG, M. (2003): From Transfer to Boundary-crossing Between School and Work as a Tool for Developing Vocational Education: An Introduction. In: Tuomi-Gröhn, T., Engeström, Y. [eds.]: Between School and Work: New Perspectives on Transfer and Boundary-crossing (pp. 1-15). Oxford, Pergamon Press.

VILNIUS MASTER PLAN 2015 - URBAN CITY DEVELOPMENT STRATEGY (2007): passed on 2007-02-14 by decision No. 1-1519 of Vilnius City Municipality Council.

WYSZOMIRSKI, M. J. (2008): The local creative economy in the United States of America. In: Anheier, H., Isar, Y. R. [eds.]: The cultural economy (pp. 199-212). London, Sage.

Initial submission 5 November 2014, final acceptance 10 July 2015

Please cite this article as:

TAFEL-VIIA, K., TERK, E., LASSUR, S., VIIA, A. (2015) Creative industries in the capital cities of the Baltic States: Are there innovations in urban policy? Moravian Geographical Reports, 23(4): 47-58. DOI: 10.1515/mgr-2015-0024. 